\title{
Alkane and alkanoic acid variations with depth in modern sediments of Pyramid Lake
}

\author{
Philip A. Meyers, Hal B. Maring ${ }^{1}$ and Richard A. Bourbonniere ${ }^{2}$ \\ Department of Atmospheric and Oceanic Science, The University of Michigan, Ann Arbor, \\ Michigan 48109, U.S.A.
}

\begin{abstract}
Pyramid Lake, a salt lake in Nevada, has undergone a $30 \%$ reduction in volume over the past $100 \mathrm{yr}$ due to diversion of river inflow for irrigation of farmland. This has altered the depositional-benthic environment and possibly has changed the overall aquatic environment of Pyramid Lake as indicated by changes in the hydrocarbon and monocarboxylic acid content in a sediment core. In the top $30 \mathrm{~cm}$, total organic carbon levels decrease from 2.5 to $1.8 \%$ dry weight but change little over the next $100 \mathrm{~cm}$. A decrease in n-alkane concentrations also occurs in the top $30 \mathrm{~cm}$, although no change in chain-length distributions is found. Most significantly, a 6-fold increase in $n$-alkanoic acid concentrations exists between the sediment surface and a core depth of $20-30 \mathrm{~cm}$ and is due primarily to high amounts of $\mathrm{C}_{28}$ and $\mathrm{C}_{30}$ acids. At all depths below $40 \mathrm{~cm}$, as well as at the surface, $C_{16}$ and $C_{18}$ acids dominate the distributions, and overall concentrations are much lower than at $20-23 \mathrm{~cm}$. These changes in concentration and in $n$-alkanoic acid chain-length distributions appear to coincide with the beginning of lake volume reduction and may demonstrate the effect of increased sedimentation rate upon organic matter preservation. In addition, changes in $n$-alkane distribution throughout this $135 \mathrm{~cm}$ sediment thickness indicate fluctuations in the relative contributions of lake-derived and land-derived organic materials.
\end{abstract}

\section{INTRODUCTION}

Organic matter in subaqueous sediments is derived from biological sources in the overlying water and in the benthic environment, from biological sources in nearby land areas, and from detrital matter eroded from geological deposits. Study of specific organic compounds isolated from different depths in modern sediments can provide information about changes in organic matter sources and about postdepositional alterations of the organic matter itself.

Geolipids, particularly aliphatic hydrocarbons and fatty acids, have been used widely as biological and diagenetic indicators. Investigation of distributions of $n$-alkanes in sediments of 3 Washington state (U.S.A.) lakes has led to the conclusion that terrigenous sources contribute most of these hydrocarbons (WAKEHAM, 1976). Total aliphatic hydrocarbon concentrations indicate an additional, anthropogenic source of hydrocarbons to modern sediments of lakes in urban areas (WAKEHAM, 1976; WAKEHAM and CARPENTER, 1976). In a survey of sediments from several oligotrophic English lakes, Cranwell (1973a) found $n$-alkane compositions to vary with the type of vegetation present in the drainage basins.

Fatty acid compositions have been interpreted as giving evidence of short-term postdepositional changes as well as of geolipid sources. CrANWELL (1974) used chain length distributions of $n$-alkanoic acids and relative amounts of branched/cyclic and alkenoic acids to distinguish between periods of eutrophy and oligotrophy as recorded in sediments of English lakes. However, such interpretations are complicated by diagenetic modifications of sedimented geolipids. Microbial activity may contribute significantly to fatty acids in sediments (BOON et al., 1975), and acids shorter than $C_{20}$ can experience more degradation than longer-chain ones (MATsuda and Koyama, 1977). In addition, unsaturated acid concentrations decrease faster than those of saturated acids in lake

\footnotetext{
'Now at: Graduate School of Oceanography, University of Rhode Island, Kingston, Rode Island 02881. U.S.A.

${ }^{2}$ Now at: National Water Research Institute. Canada Centre for Inland Waters, Burlington. Ontario L7R 4A6. Canada.
} 
sediments (Matsuda and Koyama, 1977; Matsuda, 1978; Meyers et al., 1980) and in marine sediments (FARRINGTON and QUINN, 1971a; FARRINGTON et al., 1977; VAN VLEET and QUINN, 1979).

In an effort to assess the relative importance of source and of diagenesis, GASKELL $e t$ al. (1975) examined both hydrocarbons and fatty acids in a core of recent marine sediment. Geolipids evidently could be used as valid indicators of source materials in this sediment, because they exhibited variations with depth of burial as well as evidence of good preservation over time. In the present study, geolipid compositions have been determined in a core of recent lake sediment in order to examine variations in $n$-alkane and $n$-alkanoic acid distributions over a period during which the lacustrine environment has been markedly altered.

\section{EXPERIMENTAL}

\section{Sampling}

Sediment samples were collected at $10 \mathrm{~cm}$ intervals from a $1.4 \mathrm{~m}$ gravity core taken in July 1976 from a site located in $72 \mathrm{~m}$ water in Pyramid Lake, Nevada (Fig. 1). Each sample consisted of a $3 \mathrm{~cm}$ section of the core and was placed in a solvent-rinsed jar, frozen, and shipped in dry ice to the laboratory in Michigan. Prior to analysis. samples were homogenized and wet-sieved through a $1 \mathrm{~mm}$ mesh screen to remove any large particles. Sediment grain size distributions were determined by sieving to separate sand-sized particles from finer ones and Coulter Counter analysis of the fine fraction.

Pyramid Lake is a salt lake located in western Nevada and is the largest lake in the state. Its total dissolved solids level averages $5235 \mathrm{ppm}$. The Truckee River, draining Lake Tahoe, is the only major river entering Pyramid Lake. Beginning about 1900, a large portion of the river's flow was diverted south via the Truckee Canal for farmland irrigation. Since that time, the volume of Pyramid Lake has been reduced by $30^{\circ} \%$ However, the depth of the lake $(59 \mathrm{~m}$ average) and its area $(44,600 \mathrm{ha})$ combine to make this still the largest salt lake in North America by volume. Most of the region within the Pyramid Lake watershed is desert, but the upper portions of the Truckee River are surrounded by forests.

\section{Analysis}

Total organic carbon and geolipid analyses were performed by procedures described by MEYERS and TAKEUCHI (1979) after removal of carbonates with $1 \mathrm{~N} \mathrm{HCl}$. Organic carbon was determined using a HewlettPackard Model 185B CHN Analyzer. Triplicate analyses on several samples yielded an average coefficient of variation of $3.7 \%$ around the mean.

Fatty acids and hydrocarbons were extracted from wet sediment samples by heating under reflux for $1 \mathrm{hr}$ in a mixture of $0.5 \mathrm{~N} \mathrm{KOH}$ in $95 \%$ methanol/benzene, $2 / 1$ (FARRINGTON and QuinN, 1971b). Nonsaponifiable geolipids, including hydrocarbons, were separated from saponifiable materials by adding water to the cooled saponification solvent mixture and extracting with petroleum ether. The aqueous phase was then acidified. and

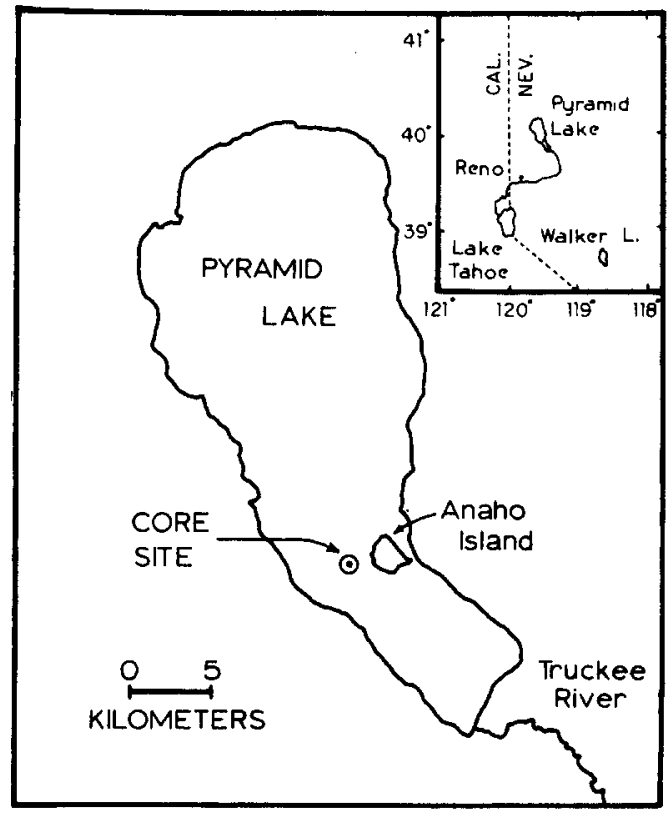

Fig. 1. Location of sediment core site in Pyramid Lake, Nevada, and its proximity to the Truckee River. Inset shows relationship between Pyramid, Walker, and Tahoe lakes. 
saponifiable geolipids, including fatty acids, were extracted with petroleum ether. Hydrocarbons were isolated from other nonsaponifiable geolipids by column chromatography. Fatty acids were prepared for analysis by methylating the dried residue of the saponifiable geolipid extract using a $\mathrm{BF}_{3}-\mathrm{MeOH}$ procedure (METCALFE et al., 1966). The resulting fatty acid methyl esters were extracted with petroleum ether and purified by thin-layer chromatography.

Gas chromatography of hydrocarbons and fatty acid esters was done with a Hewlett-Packard 5830 Reporting Chromatograph, employing $4 \mathrm{~m} \times 2.1 \mathrm{~mm}$ i.d. stainless steel columns packed with $3 \%$ SP 2100 (Supelco, Inc., Bellefonte, PA) on 100/200 mesh supelcoport and operated between 150 and $325^{\circ}$ at $4 \%$ min. Hydrocarbons and fatty acids were identified by comparison of sample peak retention times with those of authentic standards. In the absence of GC-MS verification, these identifications must be considered tentative. Amounts of these geolipids were determined by peak area integration and comparison to the area of a quantitative standard on the same chromatograph. Corrections were made for FID response differences among each class of compounds. The overall extraction and analytical efficiencies for triplicate samples of spiked sediments were $90 \pm 6 \%$ for alkanes and $98 \pm 6 \%$ for $n$-alkanoic acids. Procedural blanks showed minor amounts of contaminants as determined by gas chromatography, and the reported results have been corrected for these amounts.

\section{RESULTS}

Some general properties of this core of Pyramid Lake sediment are listed in Table 1. Water content is relatively low compared to modern sediments of the Laurentian Great Lakes (MEYERs et al., 1979) and is a reflection of the fine-sized particles constituting these core sections. Median grain size values indicate a predominantly medium to fine silt texture of this sediment. No consistent depth-related changes in grain size are obvious, nor are there any trends that occur in the amount of carbonate minerals in this core as indicated by the percentage of total inorganic carbon. Despite this evident uniformity of sediment composition, total organic carbon concentrations and geolipid compositions change over the length of the core.

Distributions of individual $n$-alkanoic acids as well as total amounts undergo variations with depth in this core as shown in Table 2. Surficial sediments contain a wide range of even-chain acids in which $\mathrm{C}_{16}$ is the dominant component. The second-most abundant saturated acid is $\mathrm{C}_{30}$, and odd-chain acids comprise $16 \%$ of the total.

Between the surface and depth of $30 \mathrm{~cm}$, sediment $n$-alkanoic acids distributions shift towards longer-chain components. The dominant acid is $\mathrm{C}_{30}$ at both $10-13 \mathrm{~cm}$ and at $20-23 \mathrm{~cm}$. In addition, the contribution of odd-chain acids increases to $23 \%$ of the total at $10-13 \mathrm{~cm}$ and to $35 \%$ at $20-23 \mathrm{~cm}$. Most of this is due to longer-chain odd-numbered acids such as $\mathrm{C}_{25}, \mathrm{C}_{27}$, and $\mathrm{C}_{31}$. Accompanying these changes in distribution, the levels of all acids are higher at $10-13 \mathrm{~cm}$ and $20-23 \mathrm{~cm}$ than in other core sections.

The distribution and amount of $n$-fatty acids in the $30-33 \mathrm{~cm}$ section are similar to those in surficial sediments. Odd-chain acids total $17 \%$ of the total, and $\mathrm{C}_{16}$ is the major

Table 1. General sedimentological properties of sections of Pyramid Lake core. Water content given as percentage of sediment wet weight. Median grainsize indicated as $\phi 50$. Total inorganic carbon (TIC) and total organic carbon (TOC) expressed as percentage of dry sediment

\begin{tabular}{ccccc}
\hline Section & $\% \mathrm{H}_{2} \mathrm{O}$ & $\phi 50$ & $\%$ TIC & $\%$ TOC \\
\hline $0-3$ & 59.9 & 6.3 & 2.52 & 2.55 \\
$10-13$ & 62.7 & 6.5 & 2.54 & 2.24 \\
$20-23$ & 60.8 & 6.6 & 2.00 & 1.82 \\
$30-33$ & 60.0 & 6.4 & 2.27 & 1.75 \\
$40-43$ & 56.7 & 6.8 & 1.83 & 1.78 \\
$50-53$ & 54.7 & 6.3 & 2.09 & 1.85 \\
$60-63$ & 52.0 & 6.8 & 2.10 & 1.80 \\
$70-73$ & 54.3 & 6.6 & 2.18 & 1.80 \\
$80-83$ & 53.4 & 6.2 & 2.55 & 1.84 \\
$90-93$ & 54.0 & 6.2 & 1.82 & 1.91 \\
$100-103$ & 43.3 & 6.3 & 2.35 & 1.89 \\
$110-113$ & 49.3 & 5.9 & 1.91 & 1.87 \\
$120-123$ & 55.3 & 6.3 & 1.42 & 1.57 \\
$130-133$ & 53.7 & 7.1 & 2.04 & 1.76 \\
\hline
\end{tabular}




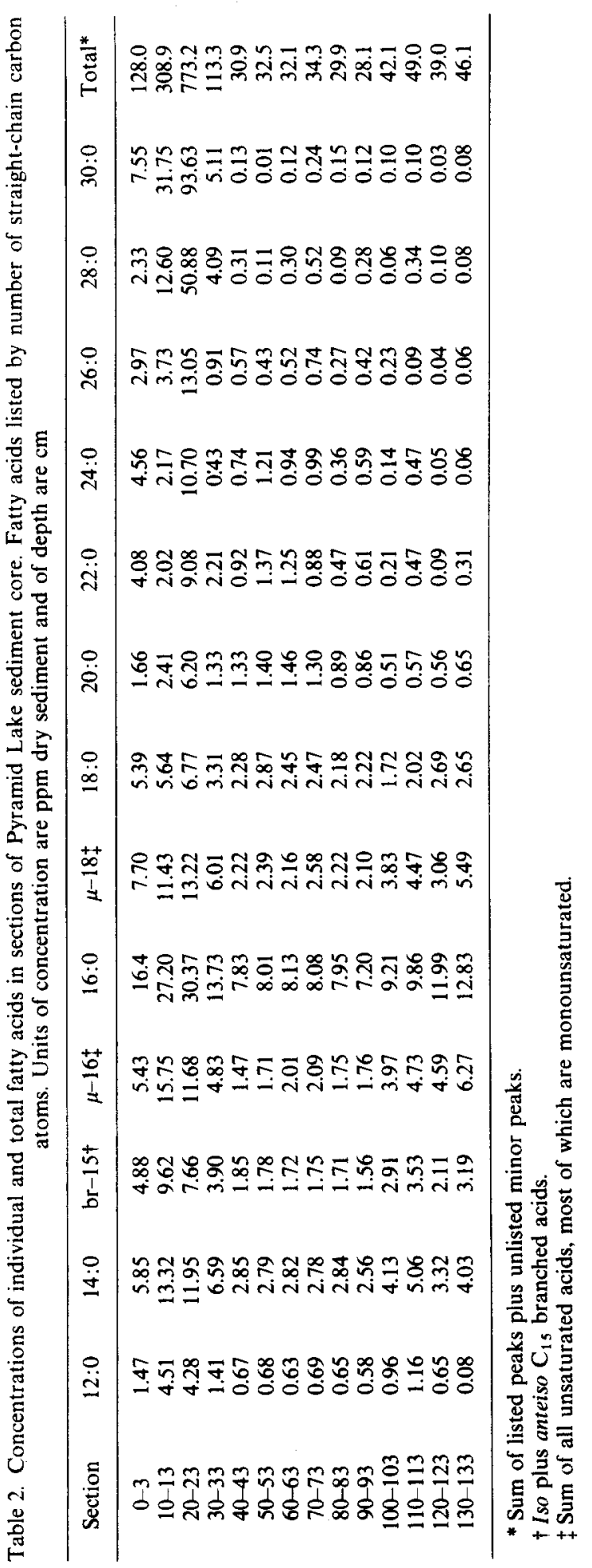

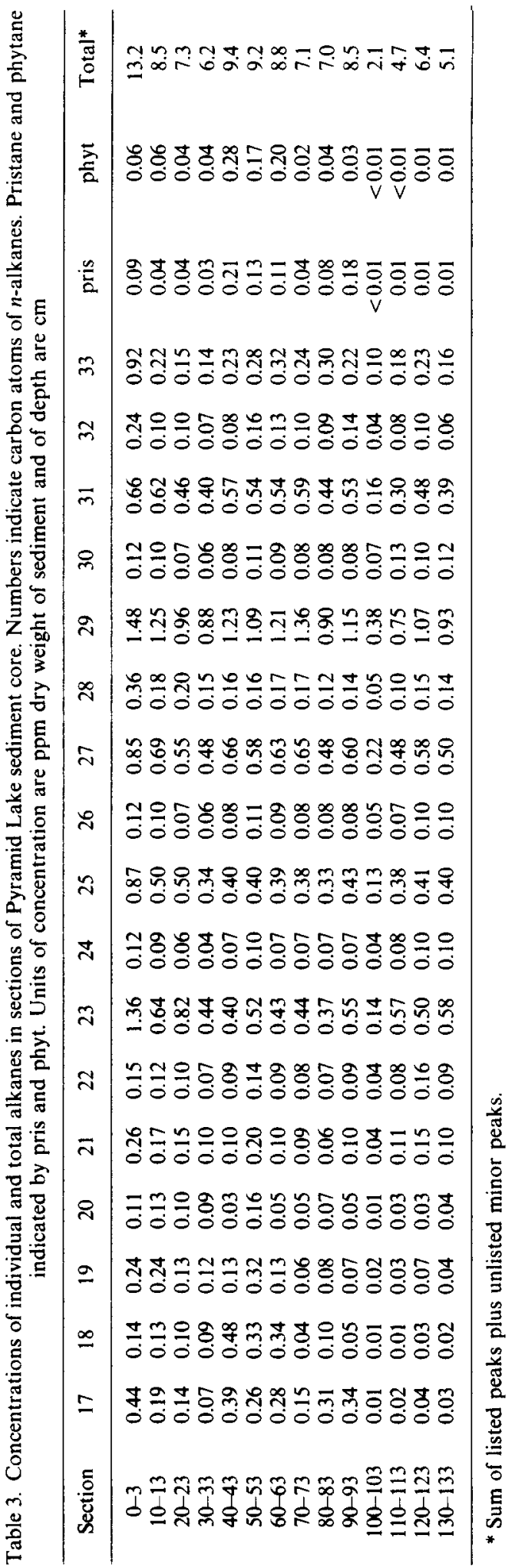


acid. The second-most abundant acid, however, is $\mathrm{C}_{14}$, although a substantial contribution of $\mathrm{C}_{30}$ still occurs.

Below $30-33 \mathrm{~cm}$, changes in distribution patterns are minor. Compositions from $40-43 \mathrm{~cm}$ to $90-93 \mathrm{~cm}$ are dominated by $C_{16}, C_{14}$, and $C_{18}$ and contain small amounts of long-chain acids. Contributions of odd-chain components are small. In the deeper sections of the core, from $100-103 \mathrm{~cm}$ to below, long-chain components are not important in the distributions. $n$-Alkanoic acid patterns are simple and centered around the $\mathrm{C}_{16}$ acid.

Table 3 lists the alkane distributions of the 14 core-sections. Total alkane concentrations are considerably less than those of saturated carboxylic acids. Surface sediments contain the highest level, and the lowest is found at a depth of $100-103 \mathrm{~cm}$. Concentrations are between $5-10 \mathrm{ppm}$ throughout most of the core. In these distributions, $\mathrm{C}_{29}$ is the dominant $n$-alkane, and this is true in all of the core sections. CPI values (CoOPER and BRAY, 1963) range between a high of 7.2 in the $20-23 \mathrm{~cm}$ section to a low of 3.0 in the $100-103 \mathrm{~cm}$ section. The mean CPI is 5.0 for all of the distributions.

The $n$-alkane distribution of surficial sediments contains almost as much $\mathrm{C}_{23}$ as $\mathrm{C}_{29}$ alkane and also substantial contributions of $\mathrm{C}_{25}, \mathrm{C}_{27}$, and $\mathrm{C}_{33}$. From 10 to $33 \mathrm{~cm}$ in this core, $\mathrm{C}_{23}$ is abundant, but $\mathrm{C}_{33}$ is not as important. The contribution of $\mathrm{C}_{17}$ also is smaller. CPI values are 5.3 at $10-13 \mathrm{~cm}, 7.2$ at $20-23 \mathrm{~cm}$, and 5.1 at $30-33 \mathrm{~cm}$. From 40 to $93 \mathrm{~cm}$, the $n$-alkane distributions are dominated by alkanes in the $n-\mathrm{C}_{23}$ to $n-\mathrm{C}_{33}$ range and are further characterized by significant contributions of $n-\mathrm{C}_{17}$. The mean $\mathrm{CPI}$ value of these sections is 4.8 , and the concentration of total alkanes undergoes little change between 40 and $93 \mathrm{~cm}$. The four sections comprising the bottom of this core are represented by distributions having few $n$-alkanes shorter than $C_{21}$. In addition, CPI values average 4.4 in these bottom sections and are generally lower than in sections higher in this core.

\section{DISCUSSION}

Concentrations of TOC in these samples of Pyramid Lake sediments are lower than those reported in sediments of eutrophic lakes (e.g. WAKEHAM and CARPENTER, 1976) and similar to those found in sediments of oligotrophic lakes such as the Laurentian Great Lakes (KeMP et al., 1972; MeYERS and TAKEUCHI, 1979). A substantial decrease in TOC with depth similar to that listed in Table 1 near the top of this core has been found in cores from Lakes Erie and Huron (KeMP et al., 1972), in Lake Suwa (Matsuda and Koyama, 1977), and in Buzzards Bay, Massachusetts (FARRINGTon et al., 1972). A more gradual decrease with depth has been found in marine sediments off shore of North Africa by Gaskell et al. (1975).

Several processes can result in these depth distributions. Increased biological productivity of surface water algal populations due to cultural enhancement of available dissolved nutrients can cause high levels of TOC in surficial sediments relative to underlying sediments. This is the most probable reason for the distributions found in Lakes Erie and Ontario by KEMP et al. (1972) and in Saginaw Bay of Lake Huron by MEYERS et al. (1979). Sediment grain size also influences the level of TOC found. Finer-sized sediments generally have higher amounts of organic carbon associated with them than coarser sediments, as demonstrated by BorDovskiY (1965) for Bering Sea sediments. In addition, sediment mineralogy can affect the character of organic materials comprising TOC, and this can modify rates of postdepositional degradation of organic matter. Such degradation to gaseous or soluble forms can also result in decrease in TOC with depth in sediment, as suggested by GASKell et al. (1975) for the distribution they observed. However, the clay fraction decreased with depth in their core indicating textural and mineralogical changes which could contribute to the TOC pattern they found. As observed by GASKELL et al. (1975), increased sedimentation rate can retard the degradation of organic matter and give rise to higher levels of TOC relative to others in a vertical profile. This process can leave an imprint at any sediment depth, including the surface. 
Combination of some or all of these factors can cause fluctuations in sediment TOC of the type documented by STEvenson and Cheng (1972) for the Argentine Basin.

The vertical profile of $n$-alkanoic acid concentratrations is interesting. In most sediments, fatty acid vertical sequences show a decrease in concentration with depth (FARRINGTON and QuINN, 1971 a; JOHNSON and CALDER, 1973; CranWELl, 1974; FARRINGTON $e t$ al., 1977; Matsuda and Koyama, 1977; Van Vleet and QuinN, 1979; MeYers et al., 1979), indicating postdepositional degradation of these materials. As observed by FARRINGTON et al. (1977) and MATSUDA and KoYAMA (1977), the loss of fatty acids proceeds most rapidly near the sediment surface. An increase in concentration over the top $20 \mathrm{~cm}$ of the Pyramid Lake sediments is indeed surprising, especially in view of the concomitant decreases in TOC and total alkanes evident in Tables 1 and 3. The simultaneous occurrence of these 3 changes over virtually the same depth suggests an alteration of the depositional environment or a radical change in the nature of the organic source material over the period of time represented by this thickness of sediment accumulation. In their analysis of lipids from an offshore marine sediment, GASKell et al. (1975) found no consistent depth trends in either character or amounts of straight-chain monocarboxylic acids, and concluded that variations in acid concentrations reflected different depositional environments.

Distributional patterns of $n$-alkanoic acids indicate both aquatic and terrigenous sources of organic materials. A large component of probably algal origin $\left(n-C_{12}\right.$ to $n-\mathrm{C}_{20}$ ) is found in all distributions. In addition, long-chain acids representative of higher plants (KVENVOLDEN, 1967) provide evidence for contribution of land-derived material (Brown et al., 1972; Gaskell et al., 1975; Matsuda and Koyama, 1977; Simoneit, 1977). A third source, bacterial lipids, is probable as postulated for both marine surficial sediments (JOHNSON and CALDER, 1973; BOON et al., 1975) and lacustrine sediments (MATSUdA and Koyama, 1977; Meyers and TaKeUCHI, 1979). However, this source is best characterized by the presence of iso and anteiso acids (Leo and PARKER, 1966; CoOPER and Blumer, 1968; Cranwell, 1973b, 1974; Johns et al., 1977) which are represented by the branched $\mathrm{C}_{15}$ acids in Table 2 .

As previously noted, the increase in subsurface alkanoic acid concentrations relative to those in surficial sediments is found mostly in long-chain land-derived acids yet also occurs in shorter-chain acids. At depths of $40-43 \mathrm{~cm}$ and deeper in this core, $n$-alkanoic acid distributions consist primarily of $\mathrm{C}_{14}, \mathrm{C}_{16}$, and $\mathrm{C}_{18}$. These chain lengths are representative of algal (ChueCAS and Riley, 1969; DeMort et al., 1972) or bacterial (Oliver and Colwell, 1973) lipids. It has been suggested from both field studies (RHEAD et al., 1972; FARRINGTON and QUINN, 1973; BOON et al., 1975; VAN VLeET and QuinN, 1979) and laboratory experiments (RHEAD et al., 1971) that the fatty acids found in many sediments are derived from microbial reworking of originally deposited organic matter. The $n$-alkanoic acid distributions found in most of this Pyramid Lake sediment core appear to agree with this hypothesis, and it is quite possible that most of the surficial acids and nearly all of the acids at $40-43 \mathrm{~cm}$ and deeper are the results of microbial alteration of primary lipids or of de novo microbial synthesis. However, the long-chain $\left(C_{22}-C_{30}\right)$ acids found in sections shallower than the $40-43 \mathrm{~cm}$ section are evidently of terrigenous plant origin, and their presence in this sedimentary sequence is indicative of some sort of change in the depositional process during the period of time represented by this core.

A possible explanation of the $n$-alkanoic acid concentration and distribution pattern changes in the top $30 \mathrm{~cm}$ of this core involves an influx of large amounts of land-derived organic matter at a time corresponding to the $10-13 \mathrm{~cm}$ and $20-23 \mathrm{~cm}$ depths. Biological and physical mixing processes could partially distribute this allochthonous material both upward into surficial sediments and downward into the section now buried at $30-33 \mathrm{~cm}$. This possibility is consistent with the introduction of agriculture into the Truckee River valley ca. 1850 followed by opening of the Truckee Canal ca. 1900. During this $50 \mathrm{yr}$ interval, irrigation water returned to the river flowed into the lake, but since 1906 much has been diverted into the Lahonton reservoir, resulting in a $30 \%$ decrease in volume of 
Pyramid Lake (BENSON, 1978). Thus, there could have been an increased input of land plant lipid material for the period $1850-1900$, then a return to conditions closer to those prior to 1850 . The vertical change in $n$-alkanoic acid concentrations and the distribution patterns indicated in Table 2 are consistent with this possibility. However, alkane concentrations do not accompany the fatty acid increases as would be expected if there had been larger input of land-derived organic matter. There are minor increases in CPI values and in $n-\mathrm{C}_{29} / n-\mathrm{C}_{17}$ ratios at these depths, both of which suggest more higher plant $n$-alkanes, but there are no increases in total organic carbon corresponding to the high levels of fatty acids.

Because of the lack of support in hydrocarbon and TOC data for a major change in source material, an explanation of the fatty acid distributions requires a change in sediment accumulation rate in this lake. As observed by GASKELL et al. (1975) and Stevenson and Cheng (1972), more rapid sedimentation rates are accompanied by higher TOC levels, implying greater preservation of organic matter due to quicker establishment of anoxic postdepositional environments in sediments. In Pyramid Lake, TOC levels decrease with depth in the top $20 \mathrm{~cm}$ of sediment, while $n$-alkanoic acid levels increase. This suggests that higher sedimentation rates resulting from a combination of agricultural irrigation, canal construction, and erosion of exposed shoreline deposits enhanced preservation of fatty acids. More labile proteinaceous and carbohydrate organic matter was not as well preserved. Presently, the Truckee River delta is experiencing active erosion as a result of lowered lake level, and this must be an additional, important source of sediment material to Pyramid Lake (BoRN, 1972). In addition, present-day biological populations of the lake may be more productive due to settlement around the lake over the past century as suggested by the higher TOC and alkane concentrations of the surficial sediment in this core.

If an episode of higher sedimentation accumulation is indeed responsible here for enhanced concentrations of fatty acids due to retarded degradation, then the geolipid data present in this core has broader meaning regarding organic diagenesis in young sediments in general. Most of the $n$-alkanoic acid distributions in Table 2 suggest an aquatic source of algal or microbial origin of these geolipids, but the $n$-alkane distributions in Table 3 indicate predominantly a terrigenous, higher-plant source (Douglas and Eglinton, 1966; Cranwell, 1973a; Giger and Schaffner, 1975). Only in the distributions of $n$-alkanoic acids in the top $40 \mathrm{~cm}$ of these sediments is there an agreement in the character of biological source between fatty acids and saturated hydrocarbons. If it is assumed that the acids in this upper portion of the core have experienced less degradation and alteration because of more rapid burial, then it is evident that most of the fatty acids in these sediments are the products of benthic production and do not reflect the original nature of the organic matter deposited in the lake bottom. This conclusion is in agreement with similar ones reached by RHEAD et al. (1971), FARRINGTON and QUINN (1973), Boon et al. (1975) Gaskell et al. (1975), and VAN VleET and QuinN (1979). Apparently, the relative lability of fatty acids reduces their usefulness as indicators of source materials in sediments except under special circumstances, such as in areas having high sedimentation rates or anoxic bottom waters.

In contrast to the apparent lability of $n$-alkanoic acids in sediments, saturated hydrocarbons seem to be resistant to alteration and therefore are useful indicators of their biological origins, as reviewed by FARRINGTON and MEYERS (1975), MORRIS and CULKIN (1975) and CRANWELl (1975).

The concentration of total alkanes in Pyramid Lake sediments is uniformly low below the surficial layer until a depth of $100 \mathrm{~cm}$ is reached. At this depth a marked decrease in concentration occurs, which is accompanied by an increase in the $n-\mathrm{C}_{29} / n-\mathrm{C}_{1}$, ratio. Although no change occurs in $n$-alkanoic acid concentrations, TOC levels become lower near the bottom of the core. Algal hydrocarbons are dominated by shorter-chain components (ClARK and Blumer, 1967; Winters et al., 1969; Youngblood et al., 1971; Giger and SChafFNer, 1975; PAOLETti et al., 1976), whereas higher land plants typically contain longer-chain $n$-alkanes (Douglas and Eglinton, 1966; Cranwell, 1973a; 
Giger and SChaffNer, 1975). Thus, the large increase in the ratio of $n-\mathrm{C}_{29}$ to $n-\mathrm{C}_{17}$ alkanes which occurs between 90 and $100 \mathrm{~cm}$ depth in Pyramid Lake sediments can signal a shift to a more terrigenous source of geolipids at this period in the lake's depositional history. Because this shift is accompanied by decreases in total alkane levels and not by increases, a smaller contribution of shorter-chain $n$-alkanes to the total is indicated below $90 \mathrm{~cm}$ rather than a larger amount of longer-chain components. Evidently, these $n$-alkane distributions record a change from an earlier period of oligotrophy to more-productive conditions in the history of Pyramid Lake which have persisted to today. At present, the lake is considered to be mesotrophic (GALAT et al., 1977).

Although actual sediment accumulation rates are not available for Pyramid Lake, there are several ways to estimate the age of the $90-93 \mathrm{~cm}$ section and thus the time of change in the trophic status of this lake. One way is to assume that modern sedimentation rates of Walker Lake, another salt lake in Western Nevada, approximate those of Pyramid Lake. These rates vary between 0.6 and $2.5 \mathrm{~mm} / \mathrm{yr}$ and average $1.5 \mathrm{~mm} / \mathrm{yr}$ by ${ }^{14} \mathrm{C}$ (BENSON, 1978). If the depth having the highest $n$-alkanoic acid concentration in Table 2 is assumed to be midway between 1850, the advent of farming, and 1906, the construction of the Truckee Canal, then an approximate age of 1875 can be assigned to the $20-23 \mathrm{~cm}$ depth. Therefore, the age of the $90-100 \mathrm{~cm}$ depth is around 1400 A.D. if the average Walker Lake sedimentation rate is assumed for the deeper portions of this Pyramid Lake cores. Another way to estimate the age of this core section is to use sediment trap accumulation information collected by ANDERSON (1977) during June, 1975. The sediment trap was positioned near the Truckee River delta during the time of high river discharge and recorded sediment accumulation rates of about $10^{-2} \mathrm{~cm} / \mathrm{day}$, or an annual rate of about $3.5 \mathrm{~cm} / \mathrm{yr}$. However, this is exceptionally high and is probably not maintained throughout a calendar year, nor is representative of the entire lake. The high spring river discharge is fed by melting snow and lasts for only a month, and the sediment load is distributed throughout the lake. Therefore, a more reasonable estimate of the sedimentation rate might be a tenth or twentieth of $3.5 \mathrm{~cm} / \mathrm{yr}$, or between 1.75 and $3.5 \mathrm{~mm} / \mathrm{yr}$. This range is close to the measured range in Walker Lake and yields an age range of 900-1700 A.D. for the period of the 90-93 cm section deposition. Although both approaches are admittedly quite speculative, they agree upon 1300-1400 A.D. as the period during which Pyramid Lake became mesotrophic. This data considerably precedes the arrival of European settlement in this region, and the shift from oligotrophy was probably initiated by natural processes, such as climatic changes.

\section{CONCLUSIONS}

(1) Combined $n$-alkanoic acid and $n$-alkane data suggest an episode of increased sedimentation which resulted in enhanced preservation of acids in subsurficial Pyrimid Lake sediments.

(2) Terrigenous sources are the primary origin of geolipids in Pyramid Lake sediments and are augmented by aquatic sources. Normal alkanes appear to be valid indicators of source materials, but fatty acids experience rapid modification in the benthic environment except under special circumstances such as rapid burial. Most $n$-alkanoic acids in Pyramid Lake sediments are probably secondarily derived from benthic microbial activity.

(3) A shift from oligotrophy towards mesotrophy is indicated by $n$-alkane distributions at a depth of $90-100 \mathrm{~cm}$ in Pyramid Lake sediments and may have occurred around $1300-1400$ A.D.

Acknowledgements-We thank R. E. MILLER for reviewing this manuscript and J. L. HAINLINE for collecting the sediment samples. Valuable information about Pyramid Lake was kindly provided by D. L. Galar. L. V. BENSON and K. Heide. Partial support of this study was granted from the Scott Turner Fund of The University of Michigan. Acknowledgement is made to the donors of the Petroleum Research Fund, administered by the American Chemical Society, for partial support of this work. 


\section{REFERENCES}

ANDERSON R. Y. (1977) Short term sedimentation response in lakes in western United States as measured by automated sampling. Limnol Oceanogr. 22, 423-433.

BENSON L. V. (1978) Fluctuations in the level of glacial Lake Lahonton for the period 0-40,000 yr B.P. Quatern. Res. 9, 300-318.

Blumer M., Guillard R. R. L. and Chase T. (1971) Hydrocarbons of marine phytoplankton. Mar. Biol. 8, 183-189.

BOON J. J., DE LeeUW J. W. and SCHENCK P. A. (1975) Organic geochemistry of Walvis Bay diatomaceous ooze-I. Occurrence and significance of the fatty acids. Geochim. Cosmochim Acta 39, 1559-1565.

BoRdovskiY O. K. (1965) Accumulation of organic matter in bottom sediments. Mar. Geol. 3, 33-82.

BorN S. M. (1972) Lake Quaternary History, Deltaic Sedimentation, and Mudlump Formation at Pyramid Lake. Nevada. Center for Water Resources, Desert Research Institute, Reno, Nevada, $97 \mathrm{pp}$.

Brown F. S., Baedecker M. J., Nissenbaum A. and Kaplan I. R. (1972) Early diagenesis in a reducing fjord, Saanich Inlet, British Columbia-III. Changes in organic constituents of sediment. Genchim. Cosmochim Acta 36, 1185-1203.

ChueCas L. and Riley J. P. (1969) Component fatty acids of total lipids of some marine phytoplankton. J. Mar. Biol. Ass. U.K. 49, 97-116.

Clark R. J., JR. and Blumer M. (1967) Distribution of $n$-paraffins in marine organisms and sediment. Limnol. Oceanogr. 12, 7987.

COOPER J. E. and Bray E. E. (1963) A postulated role of fatty acids in petroleum formation. Geochim Cosmochim. Acta 27, 1113-1127.

COOPER W. J. and Blumer M. (1968) Linear, iso, and anteiso fatty acids in Recent sediments of the North Atlantic. Deep-Sea Res. 15, 535-540.

Cranwell P. A. (1973a) Chain-length distribution of $n$-alkanes from lake sediments in relation to post-glacial environmental change. Freshwater Biol. 3, 259-265.

Cranwell. P. A. (1973b) Branched-chain and cyclopropanoid acids in a Recent sediment. Chem. Geol. 11 , 307-313.

Cranwell P. A. (1974) Monocarboxylic acids in lake sediments: Indicators derived from terrestrial and aquatic biota of paleoenvironmental trophic levels. Chem. Geol. 14, 1-14.

CRANwELl P. A. (1975) Environmental organic geochemistry of rivers and lakes, both water and sediment. In Environmental Chemistry I (ed. G. Eglinton). The Chemical Society, London.

DeMort C. L., Lowry R., Tinsley I. and Phinney H. K. (1972) The biochemical analysis of some estuarine phytoplankton species-I. Fatty acid composition $J$. Phycol. 8, 211-216.

Douglas A. G. and Eglinton G. (1966) The distribution of alkanes. In: Comparative Phytochemistry (ed. T. Swain) pp. 187-218. Academic Press.

FARRINGTON J. W. and QUINN J. G. (1971a) Fatty acid diagenesis in Recent sediment from Narragansett Bay R. I. Nature 230, 67-69.

FARRINGton J. W. and QUINN J. G. (1971b) Comparison of sampling and extraction techniques for fatty acids in recent sediments. Geochim. Cosmochim. Acta 34, 735-741.

FARRINGton J. W. and QuinN J. G. (1973) Biogeochemistry of fatty acids in Recent sediments from Narragansett Bay, R. I. Geochim. Cosmochim. Acta 37, 259-268.

FarRington J. W. and Meyers P. A. (1975) Hydrocarbons in the Marine Environment. In: Environmental Chemistry I (ed. G. EgLinton). The Chemical Society, London.

Farrington J. W., Henrichs S. M. and Anderson R. (1977) Fatty acids and ${ }^{210} \mathrm{~Pb}$ geochronology of a sediment core from Buzzards Bay, Massachusetts. Geochim. Cosmochim. Acta 41, 289-296.

Galat D. L.. McConnell W. J. and Hamilton-Galat K. (1977) Organic matter contributions to Pyramid Lake. In: Desertic Terminal Lakes (ed. D. C. GEER) pp. 371-383. Utah Water Research Laboratory, Logan. Utah.

Gaskell S. J., Morris R. J., Eglinton G. and Calvert S. E. (1975) The geochemistry of a recent marine sediment off northwest Africa. An assessment of souce of input and early diagenesis. Deep-Sea Res. 22, $777-789$.

Giger W. and SchafFner C. (1975) Aliphatic, olefinic, and aromatic hydrocarbons in recent sediments of a highly eutrophic lake. Adv. Org. Geochem. 1975, 375-390.

Johns R. B., PERRY G. J. and JACKSON K. S. (1977) Contribution of bacterial lipids to recent marine sediments Est. Coast. Mar. Sci. 5, 521-529.

JoHNSON R. W. and CALDER J. A. (1973) Early diagenesis of fatty acids and hydrocarbons in a salt marsh environment. Geochim. Cosmochim. Acta 37, 1943-1955.

Kemp A. L. W., Gray C. B. J. and Mudrochova A. (1972) Changes in C, N, P and S in the last 140 yr in three cores from Lakes Ontario, Erie and Huron. In: Nutrients in Natural Waters (eds H. E. AlleN and J. H. KRAMER) pp. 251-279. Wiley, N.Y.

K Venvolden K. A. (1967) Normal fatty acids in sediments. J. Am. Oil Chem. Soc. 44, 628-636.

Leo R. E. and PARKer P. L. (1966) Branched-chain fatty acids in sediments. Science 152, 649-650.

Matsuda H. and Koyama T. (1977) Early diagenesis of fatty acids in lacustrine sediments-I. Identification and distribution of fatty acids in recent sediment from a freshwater lake. Geochim. Cosmochim. Acta 41, 777-783.

Matsuda H. (1978) Early diagenesis of fatty acids in lacustrine sediments-III. Changes in fatty acid composition in the sediments from a brackish lake. Geochim. Cosmochim. Acta 42, 1027-1034.

Metcalfe L. D., Schmitz A. A. and Pelka J. R. (1966) A rapid preparation of fatty acid esters from lipids for gas chromatographic analysis. Anal. Chem. 38, 514-515.

MEYERS P. A. and TAKEUCHI N. (1979) Distribution of fatty acids in hydrocarbons in surficial sediments of Lake Huron. Org. Geochem. 1, 127-138.

Meyers P. A., Bourbonniere R. A. and TAKeuchi N. (1979) Southern Lake Huron: hydrocarbons and fatty 
acids in sediments. Special Publ. No. 72. Great Lakes and Marine Water Center, The University of Michigan. Ann Arbor.

Meyers P. A., Bourbonniere R. A. and TAKeuchi N. (1980) Hydrocarbons and fatty acids in two cores of Lake Huron sediments. Geochim. Cosmochim. Acta 44, 1215-1221.

MORRIS R. J. and Culkin F. (1975) Environmental Organic Geochemistry of Oceans, Fjords, and Anoxic Basins. In: Environmental Chemistry I (ed. G. EgLINTON). The Chemical Society, London.

Oliver J. D. and Colwell R. R. (1973) Extractable lipids of Gram-negative marine bacteria: fatty acid composition. Int. J. Syst. Bacteriol. 23, 442-458.

Paoletti C., Pushparaj B., Florezano G., Capella P. and Lercker G. (1976) Unsaponifiable matter of green and blue-green algal lipids as a factor of biochemical differentiation of their biomass: I. Total unsaponifiable and hydrocarbon fraction. Lipids 11, 258-265.

Rhead M. M., Eglinton G., Draffan G. H. and England P. J. (1971) Conversion of oleic acid to saturated fatty acids in Severn Estuary sediments. Nature 232, 327-330.

RheAD M. M., Eglinton G. and England P. J. (1972) Products of the short-term diagenesis of oleic acid in an estuarine sediment. Adv. in Org. Geochim. 1971, 323-333.

Simoneit B. R. T. (1977) The Black Sea, a sink for terrigenous lipids. Deep-Sea Res. 24, 813-830.

Stevenson F. J. and Cheng C. N. (1972) Organic geochemistry of the Argentine Basin sediments: carbonnitrogen relationships and Quaternary correlations. Geochim. Cosmochim. Acta 36, 653-671.

VAN VLeET E. S. and QUINN J. G. (1979) Early diagenesis of fatty acids and isoprenoid alcohols in estuarine and coastal sediments. Geochim. Cosmochim. Acta 43, 289-303.

W AKEHAM S. G. (1976) A comparative survey of petroleum hydrocarbons in lake sediments. Mar. Poll. Bull. 7 , 206-211.

Wakeham S. G. and CaR PENTER R. (1976) Aliphatic hydrocarbons in sediments of Lake Washington. Limnol. Oceanog. 21, 711-723.

Winters K., Parker P. L. and Van Baalen C. (1969) Hydrocarbons of blue-green algae: geochemical significance. Science 163, 467-468.

Youngblood W. W., Blumer M., Guillard R. L. and Fiore F. (1971) Saturated and unsaturated hydrocarbons in marine benthic algae. Mar. Biol. 8, 190-201. 